Jpn. J. Genet. (1981) 56, pp. 1-8

\title{
Chromosomal aberrations induced by hydrogen peroxide in cultured mammalian cells
}

\author{
By Hirohisa TsudA ${ }^{1)}$ \\ Biological Research Center, Central Research Institute, \\ The Japan Tobacco and Salt Public Corporation. \\ 23, Nagoki, Hatano, Kanagawa 257
}

(Received January 31, 1980)

\begin{abstract}
Chromosomal aberrations were observed in cultured mammalian cells (CHOK1 Chinese hamster cells, V79 Chinese hamster cells, Syrian hamster cells, and $\mathrm{BALB} / \mathrm{c}$ mouse cells) after treatment with hydrogen peroxide $\left(\mathrm{H}_{2} \mathrm{O}_{2} ; 0.1\right.$ $-0.5 \mathrm{mM}$ or $0.01-0.1 \mathrm{mM}$ ) for $3 \mathrm{~h}$. The cytotoxic and clastogenic effects of $\mathrm{H}_{2} \mathrm{O}_{2}$ were clearly reduced by the addition of catalase. In contrast to the clastogenic potential, $\mathrm{H}_{2} \mathrm{O}_{2}$ did not enhance the frequency of mutation in V79 cells, whether the marker for mutation was 8-azaguanine resistance or ouabain resistance.
\end{abstract}

\section{INTRODUCTION}

Irradiation with $\mathrm{x}$-ray or $\gamma$-ray of aqueous solution produces hydrogen peroxide $\left(\mathrm{H}_{2} \mathrm{O}_{2}\right)$ (Fricke 1934; Hochanadel 1952; Hart 1952). Near-ultra violet to visible light-irradiation of tryptophan aqueous solution gives rise to substances that have various biological effects including the toxicity for repair-deficient strains of Escherichia coli (Webb and Lorenz 1972) and recombinationless mutants of Salmonella typhimurium (Yoakum and Eisenstark 1972), and the inhibition of growth in cultured mammalian cells (Stoien and Wang 1974). Recently, one of these biologically active products has been identified as $\mathrm{H}_{2} \mathrm{O}_{2}$ (McCormick et al. 1976).

However, little information is available about the cytogenetic effects of $\mathrm{H}_{2} \mathrm{O}_{2}$ itself on cultured mammalian cells. Schöneich (1967) reported that chromosomal aberrations were induced by $\mathrm{H}_{2} \mathrm{O}_{2}$ in strains of ascites tumors in mice. But, his result suffers from some ambiguities in the determination of effective dose of $\mathrm{H}_{2} \mathrm{O}_{2}$, since the result is an event in ascites fluid in mouse.

In the present study, $\mathrm{H}_{2} \mathrm{O}_{2}$ was examined for its potential to induce chromosomal aberrations, and 8-azaguanine or ouabain-resistant mutation in cultured mammalian cells.

\section{MATERIALS AND METHODS}

Cell culture. Near-term embryos of Syrian hamster and back skin tissue of

1) Present address: Central Research Institute, The Japan Tobacco and Salt Public Corporation. 6-2, Umegaoka, Midori-ku, Yokohama, Kanagawa 227. 
newborn BALB/c mouse were minced by scissors, digested by trypsin $(0.25 \%$ in Hanks' salt solution), and transferred to primary cultures, respectively. V79 Chinese hamster cells were kindly supplied by Dr. T. Kuroki, (the University of Tokyo), and CHO-K1 Chinese hamster cells were kindly supplied by Dr. H. Katsuta, (the University of Tokyo). Syrian hamster cells, mouse cells and V79 cells were maintained in Eagle's minimum essential medium (MEM; Nissui, Japan) supplemented with $10 \%$ heat-inactivated fetal calf serum (GIBCO, USA), $50 \mu \mathrm{g} / \mathrm{ml}$ of Neomycin (GIBCO, USA), and $1.25 \mu \mathrm{g} / \mathrm{ml}$ of Fungizone (GIBCO, USA). CHO-K1 cells were cultured in Ham's F-12 medium (Nissui, Japan) instead of MEM. The cells were incubated at $37^{\circ} \mathrm{C}$ in a humidified incubator in an atmosphere of $5 \% \mathrm{CO}_{2}$ in air.

Chemicals. Hydrogen peroxide $\left(\mathrm{H}_{2} \mathrm{O}_{2}\right.$; Mitsubishigasukagaku, Japan) and catalase (SIGMA, USA, 3,900 U/mg) were dissolved directly in culture medium. 8Azaguanine (8AG; SIGMA, USA) was dissolved in $0.02 \mathrm{~N}-\mathrm{NaOH}$ solution $(2,000$ $\mu \mathrm{g} / \mathrm{ml})$. Ouabain (SIGMA, USA) was dissolved in hot-distilled water $(20 \mathrm{mM})$. $N$-methyl- $N^{\prime}$-nitro- $N$-nitrosoguanidine (MNNG; Wako, Japan) was dissoved in ethanol $(1,000 \mu \mathrm{g} / \mathrm{ml})$ just before the experiment.

Cytogenetic experiments. The cells (Syrian hamster cells at 2nd passage, BALB/c mouse cells at 2nd passage, CHO-K1 cells, and V79 cells) were seeded into a $75 \mathrm{~cm}^{2}$-culture bottle (Falcon, USA) at a density of $1 \times 10^{6}$ cells per bottle. Twenty-four hours after the seeding, the cells were treated with $\mathrm{H}_{2} \mathrm{O}_{2}$ for $3 \mathrm{~h}$, washed twice with Hanks' balanced salt solution and maintained for $24 \mathrm{~h}$ in normal culture medium. For the last $3 \mathrm{~h}$, colcemid $(0.1-0.3 \mu \mathrm{g} / \mathrm{ml})$ was added. The chromosomes were then prepared routinely (Rothfels and Siminovitch 1958). The classification of chromosomal aberrations is based on a system proposed by Savage (1976).

Mutation assay. Mutation was assayed with a test system involving forward mutation from 8AG- or ouabain-sensitivity to resistance. V79 cells $\left(1 \times 10^{\circ}\right.$ cells/bottle) were seeded into a $75 \mathrm{~cm}^{2}$-culture bottle. Twenty-four hours after the seeding, the cells were treated with the chemicals $\left(\mathrm{H}_{2} \mathrm{O}_{2}\right.$ or MNNG) for $3 \mathrm{~h}$, washed twice with Hanks' salt solution, and detached by $0.25 \%$ trypsin (Difco, USA) solution. Immediately after the trypsinization, the cells were reseeded into a $60 \mathrm{~mm}$ dish (Falcon, USA). For the mutation assay, $5 \times 10^{4}$ cells per dish were seeded and maintained in normal medium for $48 \mathrm{~h}$. The medium was then replaced with the selection medium (medium containing 20 $\mu \mathrm{g} / \mathrm{ml}$ of $8 \mathrm{AG}$ or $1 \mathrm{mM}$ of ouabain). These selection media were replaced twice until fixation. Ten days after the reseeding, the cells were fixed with methanol and stained with Giemsa. For the cell survival experiment, 200 cells per dish were seeded and cultured in normal medium for 7 days. The cells were then fixed and stained. The frequency of mutation was calculated per $10^{6}$ survivors. 
Chromosomal aberrations by $\mathrm{H}_{2} \mathrm{O}_{2}$

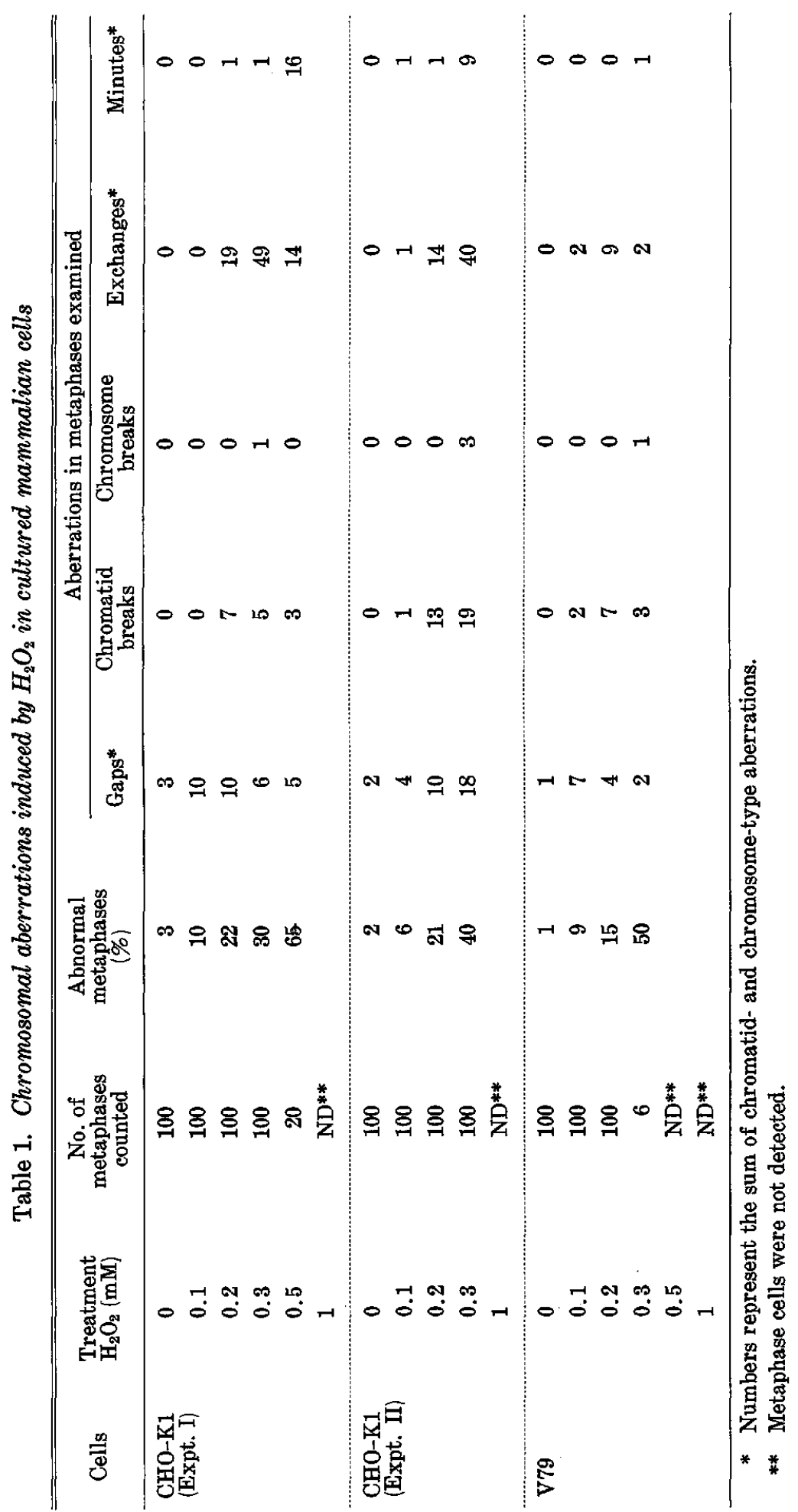


H. TsudA

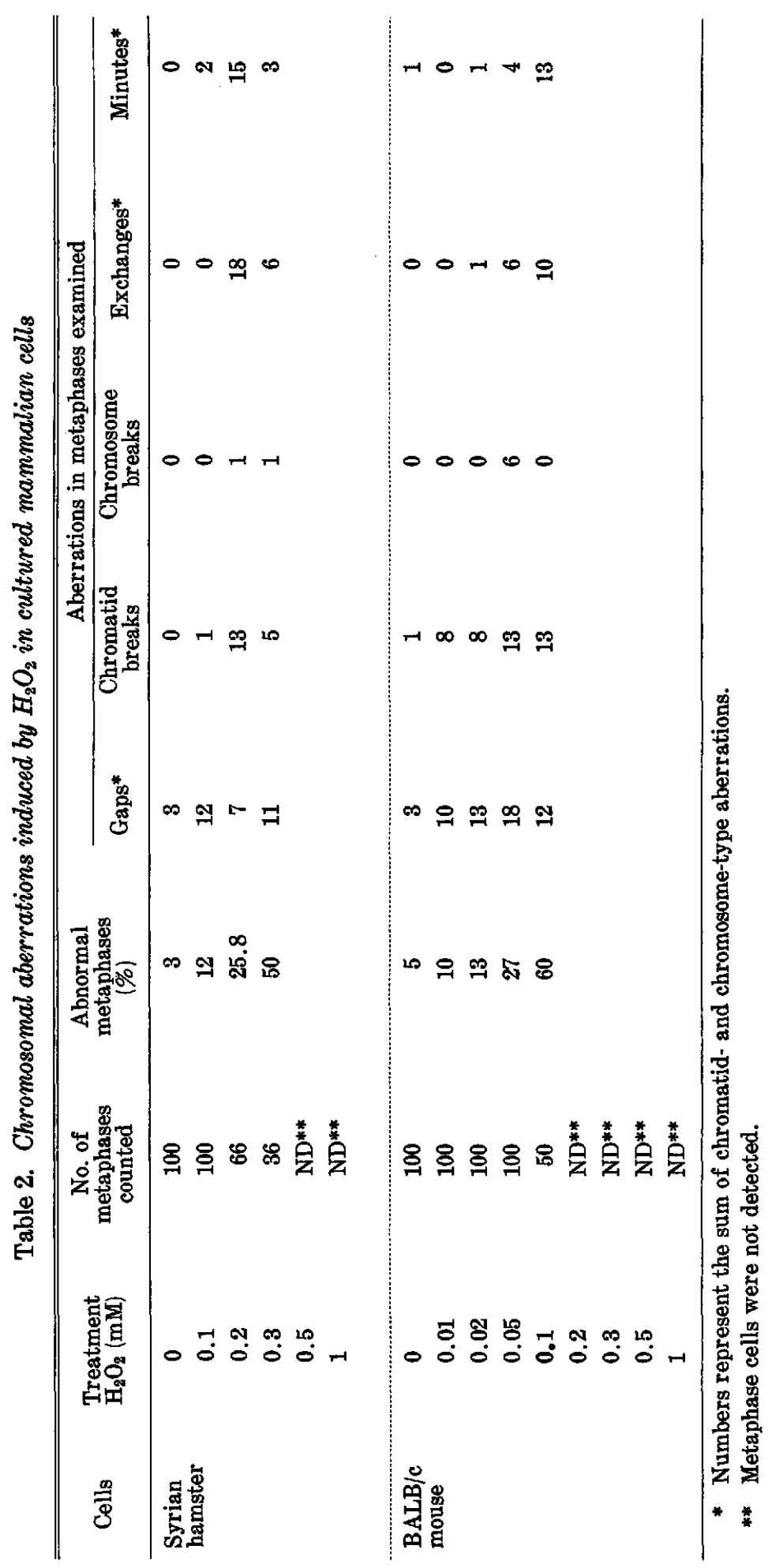



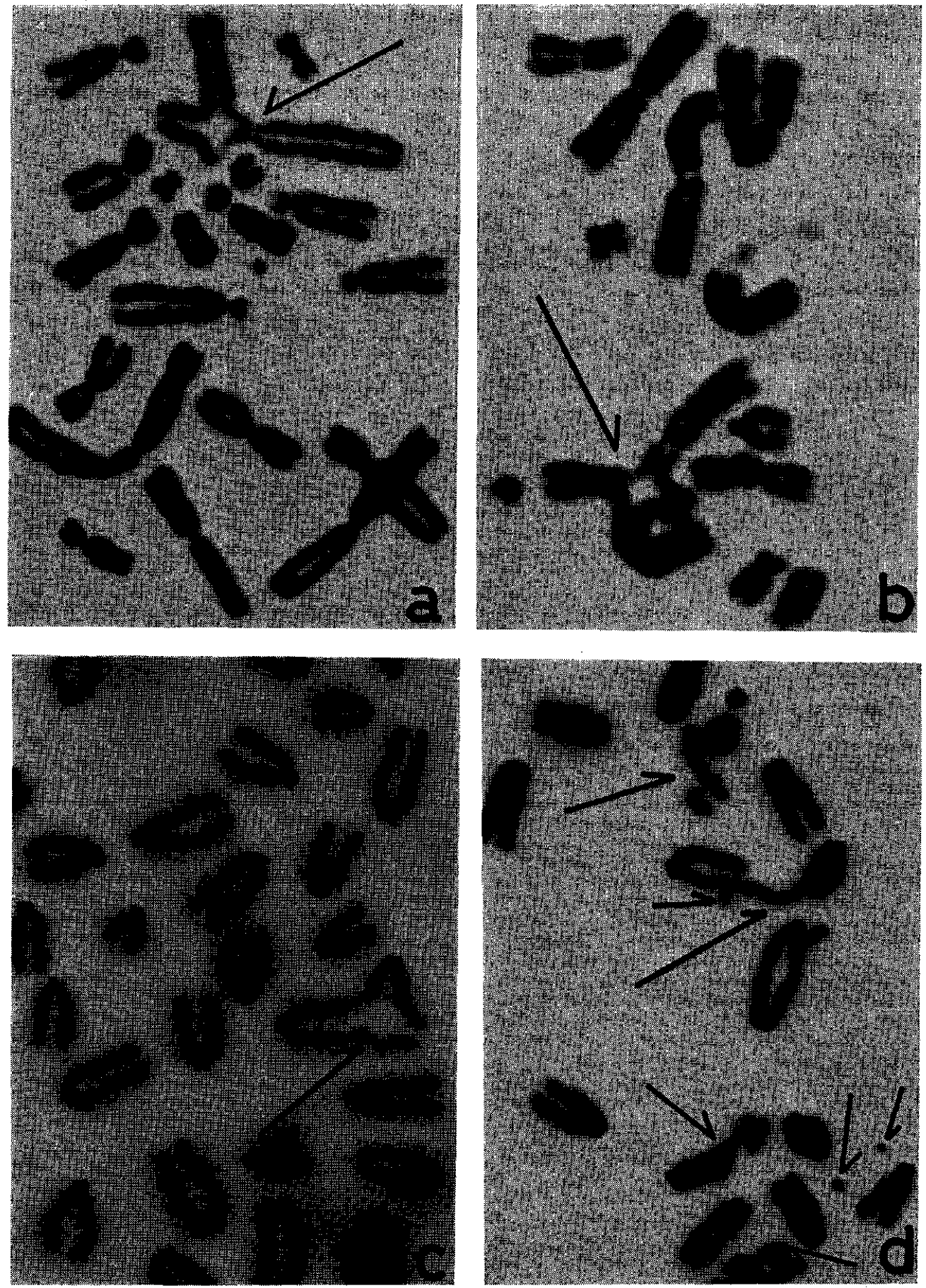

Fig. 1. Chromosomal aberrations induced by $\mathrm{H}_{2} \mathrm{O}_{2}$ in cultured mammalian cells.

a Chromatid exchange (arrow) seen in $\mathrm{CHO}-\mathrm{K} 1$ cell after treatment with $0.3 \mathrm{mM}$ of $\mathrm{H}_{2} \mathrm{O}_{2}$.

b Chromatid exchange (arrow) seen in V79 cell after treatment with $0.3 \mathrm{mM}$ of $\mathrm{H}_{2} \mathrm{O}_{2}$.

c Chromatid exchange (arrow) seen in $\mathrm{BALB} / \mathrm{c}$ mouse cell after treatment with 0.1 $\mathrm{mM}$ of $\mathrm{H}_{2} \mathrm{O}_{2}$.

d Numerous chromosomal aberrations (arrows) seen in BALB/c mouse cell after treatment with $0.05 \mathrm{mM}$ of $\mathrm{H}_{2} \mathrm{O}_{2}$. 


\section{RESULTS AND DISCUSSION}

Chromosomal aberrations. Results are shown in Tables 1 and 2 . In Chinese hamster cells and Syrian hamster cells, $\mathrm{H}_{2} \mathrm{O}_{2}(0.1-0.5 \mathrm{mM})$ induced significant amount of chromosomal aberrations including gaps, breaks, exchanges, and minutes. As the dose of $\mathrm{H}_{2} \mathrm{O}_{2}$ increased, the mitotic index decreased and damages to metaphase chromosomes increased. Especially, $\mathrm{H}_{2} \mathrm{O}_{2}$ at doses of 0.2 $\mathrm{mM}$ and $0.3 \mathrm{mM}$, induced remarkable exchange-type aberrations. On the other hand, in mouse cells (Table 2), $\mathrm{H}_{2} \mathrm{O}_{2}$ induced chromosomal aberrations at lower doses (0.01-0.1 mM) than in hamster cells. The frequency of exchange-type aberrations was not so high as that in hamster cells. Typical chromosomal aberrations induced by $\mathrm{H}_{2} \mathrm{O}_{2}$ are shown in Fig. 1 (a-d).

Reduction of $\mathrm{H}_{2} \mathrm{O}_{2}$-effects by catalase. To examine whether the effects of $\mathrm{H}_{2} \mathrm{O}_{2}$ are reduced by the addition of catalase, $1,000 \mathrm{U} / \mathrm{ml}$ of catalase was added to the cells (CHO-K1 cells) from $3 \mathrm{~h}$ before $\mathrm{H}_{2} \mathrm{O}_{2}$ treatment to the end of the treatment. Table 3 shows the result of the cell survival experiment. In the absence of catalase, $\mathrm{H}_{2} \mathrm{O}_{2}$ caused a decrease in cell survival of about $24 \%$ at $0.1 \mathrm{mM}$ and of $100 \%$ at doses higher than $0.3 \mathrm{mM}$. The cytotoxic effect of $\mathrm{H}_{2} \mathrm{O}_{2}$, however, was clearly reduced by the addition of catalase. Even at $1 \mathrm{mM}$ of $\mathrm{H}_{2} \mathrm{O}_{2}$, survived colonies were observed in the presence of catalase. Table 4 shows the effect of catalase on the clastogenic effect of $\mathrm{H}_{2} \mathrm{O}_{2} \cdot \mathrm{H}_{2} \mathrm{O}_{2}$ at $0.3 \mathrm{mM}$, induced a high rate $(30 \%)$ of chromosomal aberrations in the absence of catalase. However, in its presence, even at $1 \mathrm{mM}$, the rate of chromosomal aberrations was very low and almost the same as that of the untreated cultures.

Table 3. Reduction by catalase of the cytotoxic effect of $\mathrm{H}_{2} \mathrm{O}_{2}$ in $\mathrm{CHO}-\mathrm{K1}$ cells*

\begin{tabular}{ccc}
\hline $\begin{array}{c}\text { Treatment } \\
\mathrm{H}_{2} \mathrm{O}_{2}(\mathrm{mM})\end{array}$ & $\begin{array}{c}\text { Catalase** } \\
(1,000 \mathrm{U} / \mathrm{ml})\end{array}$ & $\begin{array}{c}\text { Relative*** } \\
\text { plating efficiency }(\%)\end{array}$ \\
\hline 0 & - & 100 \\
0 & + & 100.9 \\
0.1 & - & 76.5 \\
0.1 & + & 98.9 \\
0.3 & - & 0.0 \\
0.3 & + & 71.6 \\
1 & - & 0.0 \\
1 & + & 22.4 \\
\hline
\end{tabular}

* For measurement of plating efficiency, 200 cells were plated in a $60 \mathrm{~mm}$ dish. Three hours after the plating, the cells were treated with $\mathrm{H}_{2} \mathrm{O}_{2}$ at indicated doses for $3 \mathrm{~h}$, washed twice with Hanks, salt solution, and maintained in normal medium for 7 days. The cells were then fixed and stained. Three dishes were used to establish each point.

** Catalase was added to the cells from $3 \mathrm{~h}$ before $\mathrm{H}_{2} \mathrm{O}_{2}$ treatment to the end of the treatment. +; catalase added, -; not added.

*** Plating efficiency of untreated controls; $91.5 \%$. 
Table 4. Reduction by catalase of the chromosomal aberrations induced by $\mathrm{H}_{2} \mathrm{O}_{2}$ in $\mathrm{CHO}-\mathrm{K} 1$ cells

\begin{tabular}{cccc}
\hline $\begin{array}{c}\text { Treatment } \\
\mathrm{H}_{2} \mathrm{O}_{2}(\mathrm{mM})\end{array}$ & $\begin{array}{c}\text { Catalase* } \\
(1,000 \mathrm{U} / \mathrm{ml})\end{array}$ & $\begin{array}{c}\text { No. of } \\
\text { metaphases } \\
\text { counted }\end{array}$ & $\begin{array}{c}\text { Abnormal** } \\
\text { metaphases } \\
(\%)\end{array}$ \\
\hline 0 & - & 100 & 3 \\
0 & + & 100 & 3 \\
0.3 & - & 100 & 30 \\
0.5 & - & 20 & 65 \\
0.5 & + & 100 & 7 \\
1 & - & ND*** & \\
1 & + & 100 & 5
\end{tabular}

* Catalase was added to the cells from $3 \mathrm{~h}$ before $\mathrm{H}_{2} \mathrm{O}_{2}$ treatment to the end of the treatment. +; catalase added, -; not added.

** Percentage of metaphase cells with one or more chromosomal aberrations.

*** Metaphase cells were not detected.

Table 5. Effect of $\mathrm{H}_{2} \mathrm{O}_{2}$ on the frequency of 8-azaguanine- or ouabain-resistant mutation in V79 Chinese hamster cells

\begin{tabular}{|c|c|c|c|c|c|c|}
\hline $\begin{array}{l}\text { Marker } \\
\text { for } \\
\text { mutation* }\end{array}$ & & Treatment & $\underset{(\%)}{\text { Survival }}$ & $\begin{array}{l}\text { No. of } \\
\text { mutant } \\
\text { colonies }\end{array}$ & $\begin{array}{l}\text { No. of } \\
\text { dishes }\end{array}$ & $\begin{array}{c}\text { Mutation } \\
\text { frequency } / 10^{6} \\
\text { survivors }\end{array}$ \\
\hline \multirow[t]{5}{*}{$8 \mathrm{AG}$} & $\mathrm{H}_{2} \mathrm{O}_{2}$ & $0(\mathrm{mM})$ & 97.0 & 12 & 10 & 24.7 \\
\hline & " & 0.1 & 43.3 & 8 & 10 & 37.0 \\
\hline & " & 0.2 & 29.0 & 4 & 10 & 27.6 \\
\hline & " & 0.3 & 6.0 & 0 & 10 & 0.0 \\
\hline & MNNG & $0.5(\mu \mathrm{g} / \mathrm{ml})$ & 70.0 & 98 & 10 & 280.0 \\
\hline \multirow[t]{5}{*}{ Oua } & $\mathrm{H}_{2} \mathrm{O}_{2}$ & $0(\mathrm{mM})$ & 97.0 & 1 & 10 & 2.1 \\
\hline & $"$ & 0.1 & 43.3 & 2 & 10 & 9.2 \\
\hline & $"$ & 0.2 & 29.0 & 1 & 10 & 6.9 \\
\hline & $"$ & 0.3 & 6.0 & 0 & 10 & 0.0 \\
\hline & MNNG & $0.5(\mu \mathrm{g} / \mathrm{ml})$ & 70.0 & 64 & 10 & 182.9 \\
\hline
\end{tabular}

* 8AG; 8-azaguanine-resistant mutation, Oua; ouabain-resistant mutation.

These results suggest that the clastogenic and cytotoxic effects found in this experiment, are attributable to $\mathrm{H}_{2} \mathrm{O}_{2}$.

Mutation experiments. Results are shown in Table 5. The frequency of mutation increased significantly by MNNG which was used as a positive control. However, $\mathrm{H}_{2} \mathrm{O}_{2}$ induced neither $8 \mathrm{AG}$-resistant mutation nor ouabain-resistant mutation in our experimental conditions.

The data presented here offer unequivocal evidence for the capacity of $\mathrm{H}_{2} \mathrm{O}_{2}$ to induce chromosomal structural changes in various types of mammalian cells in vitro. The result may also present a serious problem for radiation-induced chromosomal aberrations, since $\mathrm{H}_{2} \mathrm{O}_{2}$ is produced easily by radiation of aqueous 
solution as mentioned in the top of this paper.

In contrast to the clastogenic potential, $\mathrm{H}_{2} \mathrm{O}_{2}$ did not induce significant drugresistant mutation whether the marker for mutation was $8 \mathrm{AG}-$ resistance or ouabain-resistance. At present, it is difficult to explain why $\mathrm{H}_{2} \mathrm{O}_{2}$ induces chromosomal aberrations without drug-resistant mutation. These results, however, seem to be consistent with the finding that $\mathrm{H}_{2} \mathrm{O}_{2}$ rapidly inactivates transforming activity of DNA but induces no point mutation in Bacillus subtilis (Freese and Freese 1965; Freese 1971).

The work presented in this report is based in part on the Dr. dissertation presented to the Graduate School of The University of Tokyo by the author (1979).

\section{REFERENCES}

Freese, E. and Freese, E. B. (1965) The oxygen effect on deoxyribonucleic acid inactivation by hydroxylamine. Biochem. 4, 2419-2433.

Frezse, E. (1971) Molecular mechanisms of mutations. In Chemical mutagens 1 (ed. A. Hollaender), pp. 1-56. Plenum Press, New York.

Fricke, H. (1934) The reduction of oxygen to hydrogen peroxide by the irradiation of its aqueous solution with x-rays. J. Chem. Phys. 2, 556-557.

HART, E. J. (1952) The radical pair yield of ionizing radiation in aqueous solutions of formic acid. J. Phys. Chem. 56, 594-599.

HochaNADEL, C. J. (1952) Effects of cobalt $\gamma$-radiation on water and aqueous solutions. J. Phys. Chem. 56, 587-594.

McCormick, J. P., Fischer, J. R., Pachlatko, J. P. and Eisenstark, A. (1976) Characterization of a cell-1ethal product from the photooxydation of tryptophan: Hydrogen peroxide. Science 191, 468-469.

RothFels, K. H. and Siminovitch, L. (1958) An air-drying technique for flattening chromosomes in mammalian cells grown in vitro. Stain Technol. 33, 73-77.

SAVAGE, J. R. K. (1976) Classification and relationships of induced chromosomal structural Changes. J. Med. Genetics 13, 108-122.

ScHöNEICH, J. (1967) The induction of chromosomal aberrations by hydrogen peroxide in strains of ascites tumors in mice. Mutation Res. 4, 384-388.

Storen, J. D. and WANG, R. J. (1974) Effect of near-ultraviolet and visible light on mammalian cells in culture II. Formation of toxic photoproducts in tissue culture medium by blacklight. Proc. Natl. Acad. Sci. USA 71, 3961-3965.

WeBb, R. B. and LORENZ, J. (1972) Toxicity of irradiated medium for repair-deficient strains of Escherichia coli. J. Bacteriol. 112, 649-652.

YoAKUM, G. and EISENSTARK, A. (1972) Toxicity of L-tryptophan photoproduct on recombinationless (rec) mutants of Salmonella typhimurium. J. Bacteriol. 112, 653-655. 